\section{LOS POLÍTICOS DE UMBRAL: RETRATOS POÉTICOS Y ANTIPOÉTICOS}

\author{
Guillermo Laín Corona \\ TAI. Escuela Universitaria de Artes y Espectáculos \\ glc.tai@gmail.com
}

\section{POLITICIANS BY UMBRAL: POETIC AND ANTIPOETIC PORTRAITS}

Cómo citar este artículo/Citation: Laín Corona, G. (2015). "Los políticos de Umbral: retratos poéticos y antipoéticos". Arbor, 191 (774): a252. doi: http://dx.doi.org/10.3989/ arbor.2015.774n4007
Copyright: (c) 2015 CSIC. Este es un artículo de acceso abierto distribuido bajo los términos de la licencia Creative Commons Attribution-Non Commercial (by-nc) Spain 3.0.
RESUMEN: En este artículo se aborda cómo funciona el fenómeno poético en Francisco Umbral a través de los retratos que hizo de políticos. Si bien Umbral no ejerció de poeta stricto sensu, su producción se caracteriza por un elevado uso de señales de poeticidad, y ello puede verse analizando los retratos en que alababa y criticaba a políticos.

PALABRAS CLAVE: Francisco Umbral; fenómeno poético; retratos literarios; políticos.
ABSTRACT: This article addresses the use of poetic features in Francisco Umbral's work by analysing his portraits of politicians. Although Umbral was not strictly speaking a poet, his texts were written in a very poetic manner, and this can be seen in those portraits where he praised and attacked politicians.

KEYWORDS: Francisco Umbral; poetic features; literary portrayals; politicians. 
Los políticos, mis queridos políticos, andan por aquí y por allá, por el país y por este libro, hierven en comentarios y marean agujas, van y vienen, entran y salen, crecen, nacen, viven, se reproducen y les cesan. (Francisco Umbral, Los políticos)

Lector voraz de poesía, con especial predilección por Juan Ramón Jiménez y el 27, no cabe duda de que "la poesía fue la gran pasión literaria de Francisco Umbral" (García-Posada, 2009, p. 16). Además, uno de los atributos más característicos de sus textos es su virtuosismo llámese poético, lírico o estilístico, y él solía repetir que "Todas las abundancias, buenas o malas, que haya podido haber luego en mi prosa, las he tomado de los poetas mucho más que de los prosistas" (Umbral, 1980, p. 26). Sin embargo, una aproximación a Umbral y la poesía debe evitar caer en, por así decir, mitología umbraliana, esto es, querer engrandecer a Umbral extendiendo y magnificando el alcance de sus cualidades poéticas. Y es que la idea de que él fue poeta ha sido explotada muchas veces sin una base sólida, como cuando Ramoncín (2009, p. 221) afirma que Umbral "contaba las cosas con una visión absolutamente poética". Aun habiendo mucho de cierto en esta afirmación, comentarios así, sin la apropiada justificación, están más bien guiados por la admiración incondicional: de fidelidad a la imagen de poeta que el mismo Umbral se cuidó en cultivar (pero sin reparar tal vez en lo mucho que tenía de pose y de estrategia de marketing literario) y de suponer que la imagen de poeta, por su presunto prestigio, es un modo de alabarle y promocionarle (pero sin valorar que, en la sociedad del e-book, acaso no es la mejor manera de ganarle lectores).

Miguel García-Posada (2009, p. 7), en la introducción a la Obra poética (1981-2001), coincide con Ramoncín cuando señala que "lo poético es una evidencia tangible" en todos los géneros cultivados por Umbral. A diferencia de aquel, García-Posada justifica su apreciación y, de hecho, pide "ser precisos" al hablar de lo "poético". Sin embargo, se percibe cierto grado de mitología umbraliana. Aun cuando pueda responder simplemente a estrategias de marketing editorial, el título parece sugerir que en el poemario se recoge una obra poética en sentido estricto, esto es, poemas producidos consistentemente durante veinte años. En realidad, la Obra poética (1981-2001) contiene solamente un poemario que escribió y publicó Umbral en una fecha concreta, Crímenes y baladas (1981), y unos poemas que escribió también en unas fechas muy concretas mucho después: entre 2000 y 2001 (con algún poema de 2002). No es, por tanto, toda una obra poética, sino más bien una colección de poemas escritos de manera ocasional y en cierto modo diletante. Del último grupo de poemas, Umbral apenas publicó ninguno en vida, y hay que considerarlos más bien como un "diario poético" personal: están datados con día, mes y año, como reacción a temas de actualidad y como gimnasia a escondidas, para "probarse a sí mismo en el ejercicio de una disciplina tan antigua como grata" (García-Posada, 2009, p. 18). No obstante, García-Posada insiste: “Aunque razones más prácticas que otra cosa determinaron su apartamiento del género poético strictu senso", Umbral es "un poeta por encima de cualquier otra consideración" (pp. 25 y 26).

Para sustentar esta opinión, García-Posada parte de la idea de que "es un error considerar que el verso detenta el monopolio de lo poético. En el Quijote hay más poesía que en la inmensa mayoría de los libros de versos" (p. 7). La idea tiene una historia sólida, que entronca con el Romanticismo, el Modernismo y las vanguardias, así por ejemplo Pedro Salinas en su artículo canónico "El signo de la literatura española del siglo XX" (1940). Para este crítico-poeta, lo que caracteriza toda la literatura del siglo $\mathrm{XX}$, por encima de los géneros, es el "signo lírico". Un "lirismo básico, esencial (lirismo no de la letra, sino del espíritu)" que se vierte sobre todos los géneros: "novela, ensayo, teatro, esa ardiente tonalidad poética que percibimos en la mayoría de las obras importantes de nuestros días" (Salinas, 1979, pp. 34-35). Pero una actitud así tiene problemas metodológicos. Por un lado, Salinas escribe en 1940 refiriéndose a toda la literatura del siglo $\mathrm{XX}$, si bien hoy difícilmente podríamos aplicar el signo lírico a, por ejemplo, novelas fundamentales del realismo social en España. Por otro, peca en cierto modo de imprecisión: sí, puede haber poesía en todo texto; pero no, no todo texto es poesía.

Desde hace ya tiempo, y ante la dificultad de una definición objetiva, se viene aceptando la necesidad de analizar la literatura desde el punto de vista de la recepción: cómo es percibida al ser consumida, atendiendo particularmente a los gustos de cada época. La idea formalista "de la poesía como «desviación» de la norma" (el extrañamiento de Víktor Shklovski) o de prevalencia de la función poética (Roman Jakobson) en última instancia "no depende más que del destinatario", circunscrito a su época. Un eslogan publicitario en verso rimado puede tener un grado de extrañamiento respecto del lenguaje cotidiano mayor que una novela, y sin embargo se entiende que en el eslogan la función poética es secundaria porque "la 
identificación de la dominante queda siempre confinada al público". En efecto, el receptor actual percibe en el eslogan lo poético como secundario porque lo reconoce como anuncio comercial (función primaria). Sin embargo: "En una enciclopedia medieval en verso hoy podemos ver como dominante la función poética (porque no estamos habituados a buscar la ciencia en los textos en verso)". Esto no implica que la literatura sea solo tal a costa de lo que interprete el lector al recibir el texto, sino que este puede ser diseñado como literatura desde su producción. Pero ello es así porque el escritor usa "marcas típicas de literariedad", comunes a quien escribe y a quien lee (Brioschi y Di Girolamo, 2000, pp. 77, 79 y 80).

O sea, la literatura lo es porque el escritor usa y el lector (re)conoce una serie de marcas o señales de literariedad. Estas señales pueden ser de muy vario tipo y dependen en gran medida de la época. En el caso de la poesía, señal de poeticidad puede ser simplemente el continente: un poema es concebido y percibido como tal si aparece en un libro de poemas (poemario). O puede ser una cualidad formal del texto: disposición en verso. $\mathrm{O}$ algo tan volátil según las épocas como la temática: en la Grecia Antigua, poesía era la astronomía (Urania), si bien desde el Romanticismo queda la impresión de que la poesía tiene que ver casi exclusivamente con la exaltación de los sentimientos y emociones del poeta (identificación de poesía y lírica). Es, de hecho, esta manera postromántica de entender la poesía como lirismo lo que permite decir que hay textos que, sin ser poemas, son poéticos (Brioschi y Di Girolamo, 2000, p. 125), como hacen Pedro Salinas y, en torno a Umbral, García-Posada. Cuando se dice que cierto texto es poético suele significar que en él el autor se expresa como el poeta en la lírica.

Ahora bien, aunque un texto, por las razones que sea, pueda ser percibido con un cierto e incluso con un alto grado de poeticidad, no por ello ha de ser poesía. El propio García-Posada, que reconoce en efecto que Umbral estuvo apartado de la poesía como género strictu senso, da:

Una advertencia: poeticidad y literariedad son categorías contiguas, pero que no deben confundirse. Son contiguas porque designan ambas la conversión de lo extraestético en artístico; poeticidad se aplica a la poesía. (2009, p. 10)

Quiere decirse: la poeticidad es una forma particular de literariedad, de modo que un texto puede ser literario, pero no por ello ha de ser poético. O, lo que es más importante en el caso de Umbral: puede tener rasgos poéticos (incluso muchos), pero no los suficientes como para concretarse (ser percibido) como poesía, sino solo como literatura. En efecto, esto es lo que pasa con los textos de Umbral, y esto es lo que GarcíaPosada, por más que quiera usarlo para defenderle como poeta, ofrece en última instancia en su análisis: ciertas condiciones de poeticidad que se repiten en los textos de Umbral. Así:

Primera condición de la poeticidad: la escritura perpetua. Usó Umbral el concepto a propósito de González-Ruano; él se dedicó a la literatura con pasión absoluta, rehén gozoso de esa escritura. La escritura como forma de afirmación, como forma de vida. Vivir y escribir son la misma cosa. (p. 10)

Asimismo, García-Posada establece otras condiciones de poeticidad, como (i) el cuidado de "la forma interior de la lengua" (p. 13). Se refiere también al (ii) "enganche con la tradición" (p. 13), esto es, la retroalimentación literaria, la construcción de la literatura a partir de otra literatura. Finalmente, habla este crítico de (iii) la autonomía literaria -“lenguaje liberado de la suprema responsabilidad de la información" (p. 14) y "primacía de lo estético" (p. 15)-; del (iv) tono lírico (p. 22), y (v) el uso constante de la metáfora (p. 23).

Nótese, sin embargo, lo problemático de su razonamiento. García-Posada advierte de la diferencia entre literariedad (hecho general) y poeticidad (hecho particular), pero muchos de los rasgos con los que quiere justificar la poeticidad de los textos de Umbral son más bien propios de la literariedad. Piénsese en la condición de escritura perpetua. ¿Por qué la pasión constante por escribir ha de ser un rasgo particular de poeticidad? ¿No puede un novelista sentir una misma pasión perpetua por escribir? Sin ir más lejos, Umbral escribía constantemente en la Prensa y entendía el periodismo como una "pasión diaria" (Gracia Armendáriz, 2003). No obstante esta pasión, muchas columnas suyas no son poéticas: no reúnen apenas ninguna de las condiciones descritas por García-Posada (a no ser la de la escritura perpetua, que, como se ha dicho, no es necesariamente un rasgo de poeticidad, sino en general de literariedad). Por ejemplo, Jean-Pierre Castellani (2009, pp. 54-55) explica que, frente a sus mejores columnas, en que se enfoca "de modo poético" la actualidad, "en los últimos años de colaboración en El Mundo" los artículos de Umbral tienden a perder su carga de poesía porque gana "demasiada importancia [...] el análisis político".

Con todo, no se puede negar que Umbral cultivó la poesía. Si seguimos el razonamiento de las señales 
de poeticidad, una de las más incuestionables para cualquier lector es la disposición del texto en verso. En este formato, sí, Umbral cultivó la poesía, pero, como ya se ha visto, poco y de manera esporádica. Además de los poemas recogidos en su Obra poética (1981-2001), hay también algunos poemas sueltos en libros de varia índole, como en Mis paraísos artificiales (1976). Por otro lado, es justo decir, con GarcíaPosada, que el verso no detenta el monopolio de la poesía. En Crímenes y baladas, solo nueve poemas están en verso. Pero los demás, aunque en prosa, son poemas de pleno derecho, de nuevo siguiendo los postulados de la recepción. Para empezar, están recogidos en un poemario. Además, tanto en verso como en prosa, todos los textos comparten un formato similar: son composiciones breves (un par de páginas, a lo sumo) en torno a un tema/imagen. Y, en todo caso, aun cuando aparecen sobre la página sin la disposición tipográfica del verso, los textos en prosa están también metrificados. Por ejemplo, "Cadáver de domingo" (Umbral, 2009, pp. 34-35) está dispuesto en versos alejandrinos, y "Herramienta del cielo" (p. 40), aunque con la disposición tipográfica de la prosa, también se puede analizar con esa métrica.

O sea, hay señales que apuntan a que Umbral en efecto cultivó la poesía en sentido estricto (poemas, en prosa o verso). Pero ni el magro número de composiciones de este tipo (unas doscientas en su Obra poética (1981-2001), frente a las decenas de miles de artículos que publicó), ni la falta de sistematicidad en su producción permiten afirmar con rotundidad que Umbral fue un poeta como tal. Como resumía Luis María Ansón (24 julio 2009), Umbral: “Deja para la historia de la Literatura una prosa poética encendida de endecasílabos, incendiada de hallazgos audaces. Pero no fue un poeta. Dios le sustrajo, como a Cervantes, ese don. Y él lo sabía. Por eso, tras Crímenes y baladas, [...] Umbral no quiso publicar más versos, salvo algún poema aislado en El Cultural".

Pero si no se puede decir que fuera un poeta de poemas, lo cierto es que Umbral cultivó (abundantemente) un tipo de prosa poética. No ya en el sentido de poemas en prosa como los de Crímenes y baladas, sino textos en prosa que, sin ser poemas como tales, están escritos de manera muy cercana a la poesía. Ahora bien, también sería un error de mitología umbraliana considerar que toda su obra es poesía en prosa y, de ahí, concluir por ello que Umbral fue poeta. Como he explicado recientemente en otro lado (Laín Corona, 2014a), muchas obras de Umbral, como Las ninfas (1976) o Las giganteas (1982), se han tomado meramente como poesía en prosa. Sin embargo, en estas obras los rasgos poéticos, más que funcionar per se para hacer sendos poemas en prosa, trabajan al servicio de una forma de narración y sirven para conformar un tipo de novela que, aunque de naturaleza lírica, no deja de ser novela, al estilo Modernist de Virginia Woolf, Marcel Proust o, en España, Gabriel Miró. Algo parecido ocurre con su labor periodística. En efecto, Umbral resaltaba frecuentemente el carácter literario y poético del periodismo: "el artículo es un género, y concretamente un género literario". Y añade: "Lirismo más actualidad se potencian mutuamente y esa es la clave de la columna" ("Benítez Reyes, columnista", El Mundo, 12 diciembre 2000)1. Sin duda, muchas columnas suyas están cargadas de poeticidad, y lo que aquí resalta Umbral es el lirismo: combinar la actualidad con la particular mirada subjetiva del escritor. Pero, sin contar ciertos casos (algunos se verán más adelante) en que Umbral usó el espacio de su columna para insertar sin más un poema stricto sensu (en prosa o en verso), en todos los demás, por muchos rasgos poéticos que haya, al aparecer en un periódico (a su servicio y con muchas de las convenciones del género), la función que se percibe como dominante tiene que ser la periodística, aun de opinión, al igual que se percibe como dominante la función publicitaria en un eslogan, aun estando en verso. De hecho, Umbral, en el mismo artículo de "Benítez Reyes" habla de "heterodoxia dentro de la ortodoxia del periódico". O sea, aunque sui generis, periodismo, al fin y al cabo.

Todas estas consideraciones son importantes para abordar el análisis de los retratos que ofrece Umbral en su inmensa producción literaria y, en especial, periodística. Para hablar de retrato como "Descripción de la figura o carácter, o sea, de las cualidades físicas o morales de una persona" (por tomar la segunda acepción del DRAE, 22aㅡ. ed.), parece razonable ceñirse a personas reales. En efecto, Umbral retrató por escrito a relevantes personalidades públicas: literatos, intelectuales, artistas, periodistas, etc. Para estos retratos, Umbral se vale en numerosas ocasiones de rasgos poéticos, si bien no por ello el retrato resultante tiene por qué ser necesariamente un poema como tal (aunque puede serlo). El retrato poético de Umbral es, por tanto, un texto en el que se describe a una persona real usando elementos propios de la poesía (metrificación, tropos, figuras de repetición, lirismo, etc.), y en algunos casos puede ser un poema de pleno derecho.

Así entendido, el retrato poético lo es en sentido amplio: un retrato con características poéticas para 
alabar o para criticar a una persona. Lo contrario del retrato poético en este sentido es el retrato no poético, esto es, sin uso de señales de poeticidad. Ahora bien, el retrato poético se usa aquí también en un sentido restringido: el texto que retrata con rasgos poéticos a una persona de manera positiva (alaban- za). Frente a esto, el retrato antipoético sería un texto en el que, con rasgos poéticos, se presenta a una persona de manera negativa (ataque). El retrato poético de sentido amplio (SA) contiene al retrato poético de sentido restringido (SR) y al retrato antipoético:

\begin{tabular}{|l|l|}
\hline \multirow{2}{*}{$\begin{array}{l}\text { Retrato poético }(S A): \\
\text { Retrato de persona usando elementos poéticos }\end{array}$} & $\begin{array}{l}\text { Retrato poético }(S R) \text { : } \\
\text { Retrato poético en sentido amplio para alabar a una per- } \\
\text { sona }\end{array}$ \\
\cline { 2 - 2 } & $\begin{array}{l}\text { Retrato antipoético: } \\
\text { Retrato poético en sentido amplio para atacar o_ridiculizar } \\
\text { a una persona }\end{array}$ \\
\hline \multicolumn{2}{|c|}{ Retrato no poético: } \\
\hline
\end{tabular}

Dado el escaso espacio de un artículo de revista, he limitado el campo de estudio a los retratos poéticos que hizo Umbral de políticos (en adelante, se hablará de retratos poéticos, según los casos, en sentido amplio o restringido). Como parto del retrato de personas reales, es conveniente analizar textos de no ficción, en los que Umbral se refiere con mucha frecuencia a políticos (no entro aquí en la interminable problemática del grado de ficcionalización a que somete Umbral todos sus textos, incluidos los supuestamente no ficticios, como las biografías). Analizaré, por ellos, libros como Crónica de esa guapa gente: Memorias de la jet (1991) o Diario político y sentimental (1999), así como sus artículos periodísticos. Estos son especialmente relevantes para este estudio porque Umbral (1999, p. 44) considera el periodismo un lugar adecuado para la poesía: "la poesía lírica la vendo todos los días en el periódico". Además, como orgulloso periodista, lo fue en gran medida como cronista político, de ahí su libro Los políticos (1976). Finalmente, como son tan abundantes los políticos en la carrera literaria de Umbral, el análisis de retratos poéticos de este colectivo es representativo de los retratos poéticos de otros personajes.

Lo primero que se puede analizar es el grado de poeticidad de los retratos poéticos. Ello depende del tipo y de la cantidad de señales de poeticidad, gradación que a continuación se irá analizando de más a menos. En este sentido, se puede hablar del retrato poético autónomo, esto es, un texto que está dedicado en su totalidad a retratar con rasgos poéticos a alguien y que tiene sentido completo por sí mismo (el retrato no es una parte de un todo mayor). De este tipo de retratos, tiene una poeticidad más marcada el que se presenta en forma de poema, en prosa o verso: el retrato poético autónomo es un poema, no meramente un texto con rasgos poéticos. Entre las composiciones que hizo Umbral en 2000-2001, hay dos poemas a Adolfo Suárez, el político que lideró la Transición española como Presidente del Gobierno (1976-1981). Uno de estos poemas resume la admiración que Umbral le profesó a este político, constituyendo, así, un retrato poético autónomo en sentido estricto de alabanza:

Adolfo, Castilla en armas.

El mozo que violentó la Historia.

[...]

Desde entonces preside mi memoria,

la memoria de un pueblo y su aventura,

la memoria de un pueblo comunero.

(Umbral, 2009, p. 287)

Otro poema de este libro sirve de ejemplo de retrato poético autónomo en forma de poema en prosa metrificada (esencialmente, eneasílabos). Sin fecha, pero de la misma época (en torno al año 2000), se lo dedica Umbral (2009, p. 283) "Para una Reyna triste": Sofía de Grecia. Entre la alabanza a la persona y la compasión que le merece por el oficio monárquico, como prefigura el título mismo, Umbral la describe, líricamente: "Blanca y delgada, rubia y triste, / como una Reyna dibujada" [El poema está dispuesto en prosa; aquí se añaden barras para remarcar la metrificación propuesta: en este caso, eneasílabos. En adelante, se añaden barras a los textos de Umbral en prosa metrificada para remarcar los esquemas métricos que se proponen en este estudio]. Reyna con y es una manera de aumentar el grado de poeticidad por mediación del arcaísmo. Asimismo, Umbral se vale de figuras retóricas propias de la poesía, como este paralelismo sintáctico y silábico con anáfora: "oro de ley el denso pelo, / oro de ley el alma 
clara". Finalmente, el grado de poeticidad queda recalcado por la intertextualidad, y es que la temática, el tono arcaizante y el lenguaje sinestésico (denso, clara) sugieren la huella del Modernismo hispánico, y de hecho Ansón (24 julio 2009) dice, poniendo como ejemplo precisamente este poema: "Se enredan los poemas de Francisco Umbral en las raíces de Valle Inclán, de Juan Ramón, de Rubén". Considérese la "Sonatina" de Rubén Darío (2000, pp. 105-07) en sus Prosas profanas y otros poemas (1896). Como la reina de Umbral, Darío habla aquí de una princesa triste por sus obligaciones dinásticas y se vale de un lenguaje plástico y paralelismos parecidos como: "Está presa en sus oros, está presa en sus tules" (v. 32), también con referencia al oro. ${ }^{2}$

Los retratos poéticos autónomos en forma de poema aparecen también en Prensa, si bien su naturaleza de poema se ve ligeramente degradada por presentarse en el espacio del artículo, no en un poemario. No obstante, por todo lo demás, es evidente que se trata de poemas, y, como los del período 2000-2001, los escribe Umbral como respuesta inmediata a la actualidad. Algunos de estos casos son poemas en verso, como su "Carta de Antonio Machado" (El Mundo, 31 mayo 1990), retrato antipoético de Alfonso Guerra del que se hablará más adelante. Sin embargo, lo más frecuente en el marco periodístico es el retrato poético en forma de poema en prosa metrificada. Así, su columna "A Loyola" (EI Mundo, 2 marzo 1998) ${ }^{3}$, esto es, Loyola de Palacio, Ministra de Agricultura (19961999) con José María Aznar. Representante de España para la Unión Europea en las negociaciones de política agraria, Umbral, en alejandrinos, la alaba líricamente a la luz de la imagen española del olivo y el aceite. Véase el comienzo, identificada con Eva por su rebeldía contra las directrices europeas en torno a las cuotas de cultivo del olivo, en clara equivalencia con la decisión en la Biblia de tomar la manzana del árbol:

Ah niña del aceite, Loyola del Olivo, / ah el puro aceite virgen y la virgen ministra, / se encontraron un día estas virginidades, / Eva blanca y adánica, clara serpiente verde, / y hoy Loyola se unge, se empeña en una lucha, / salvemos el aceite, salvemos los olivos, / sangre verde de España, herida y andaluza.

Al final del artículo/poema, Umbral muestra que su alabanza poética no se debe tanto a que comulgue con la ideología conservadora del partido de la ministra, como a la defensa de los intereses y la idiosincrasia de España, en sintonía, según él, con los socialistas:

Avanza el bosque verde con filos de resoles, / el sol es arsenal de lancería, / ni el socialista quiere ni mi
Loyola quiere / que se lleven España arrancando los mapas. / Avanza el bosque verde, como el bosque de Shakespeare, / hacia el mal enemigo, hacia el negro contable / que les habla a las hojas con acento extranjero, / que morirá de bala de aceituna suavísima. / Loyola y la serpiente, estampario pagano, / Loyola y el aceite, rebelión de los campos. / Pan y aceite es España y una virgen violeta.

Umbral, que ha deslizado un endecasílabo para introducir una metáfora ("el sol es arsenal de lancería"), enfatiza el grado de poeticidad con una referencia literaria al ejército camuflado con ramas del bosque de Birnam que, en el Macbeth de Shakespeare, ataca el castillo de Dunsinane. Con ello, sugiere que se trata de una lucha común de todos los españoles (el ejército) contra las políticas agrarias europeas de los funcionarios de idioma extranjero (el castillo escocés). El colofón final al violeta tal vez se deba al color de la ropa que llevara la ministra en alguna imagen que viera Umbral en Prensa o televisión, en cuyo caso estaría respondiendo de nuevo a estímulos de la actualidad. Sea como fuere, es un contraste sinestésico con el verde que domina todo el texto, fortaleciéndose así la poeticidad.

Es más frecuente que los retratos poéticos de Umbral no sean poemas como tales, aun siendo retratos autónomos y aun manteniendo una marcada poeticidad. Con motivo de su retirada de la arena política, Umbral escribe "Se va Fernando Morán" (El Mundo, 4 diciembre 2000), quien fuera, entre otros cargos, Ministro socialista de Asuntos Exteriores (1982-1985). No hay aquí un verdadero poema en prosa, no solo por la ausencia de prosa metrificada, sino porque Umbral rompe a veces el tono poético para analizar cuestiones ideológicas, a la manera del periodismo de opinión corriente. Por ejemplo, lamentando la pérdida que sufre el partido con su retiro, Umbral reflexiona: "así es como el PSOE ha encontrado su manera de desaparecer, de transicionarse en un partido liberalmonetarista que vive de improvisaciones y ya no pronuncia nunca la palabra socialismo". Ahora bien, como está dedicado por entero a este político y porque tiene suficientes rasgos de poeticidad a lo largo de todo el texto, se puede considerar un retrato poético autónomo, y de hecho lo es en sentido restringido. Umbral alaba al hombre con un lenguaje cargadamente figurado, como cuando se destaca metonímicamente que, con la ausencia de la persona (el todo) queda el humo de la pipa y la pajarita (la parte): "En el tiempo no dejas sino un humo de pipa, un pensativo humo, la craquelada pajarita al cuello, y la aureola cenicien- 
ta de tu persona, ese vacío imperceptible que dejan apenas los hombres honrados". Asimismo, es notablemente figurado este caso, particularmente por el uso del símil: "Siempre la frente como un palimpsesto de pensamiento, siempre las cejas quebradas y una paz triste en la cara". Finalmente, destaca el tono lírico, por medio de la exaltación de sentimientos:

Adiós, viejo socialista, viejo luchador, poderoso hombre de ceniza, debilísimo intelectual de amianto. [...] bohemio intelectual que quisiste ser, que en el fondo eres, inmolado siempre, por veces con toda eficacia y brillantez, a la diplomacia y el poder.

Frente a ejemplos como este, que puede tomarse por retrato poético autónomo, en otros casos el texto no está dedicado por entero a hacer el retrato de un político y/o el tono no es poético de manera constante. Pero sí se desliza, dentro del texto, alguna pincelada poética, y esa pincelada puede tomarse como retrato poético breve. Se trata, pues, de retratos poéticos no autónomos, esto es, integrados en y dependientes de un texto más amplio (en adelante, se usa por igual breve y no autónomo). A veces, este texto amplio puede estar dedicado por entero a un político, pero no habla Umbral del político para hacer un retrato, sino a tenor de cualquier otra cosa. Ahora bien, en estos casos no es sorprendente que se deslice algún retrato poético breve. En su Diario político y sentimental, Umbral se detiene en la entrada del 4 de octubre de 1997 a relatar una charla mantenida en persona con don Juan Carlos I. No es un retrato como tal, sino una reflexión sobre su papel en la monarquía parlamentaria. Sin embargo, se desliza un retrato poético breve del Rey (y retrato nunca mejor dicho, ya que se habla de rasgos pictóricos):

$Y$ en el color risueño de sus ojos hubo un momento de luz grave, porque le entraba por un ventanal el sol de la hora madura, esos oros y ocres y azules que tanto relaciona mi imaginación con los Borbones, con más memoria pictórica que histórica. [...] Le trato desde que es rey y nunca le había visto en Rey, a la luz tensa y extensa de la tarde. (Umbral, 1999, p. 38)

Dedica Umbral el artículo "Cansadamente humanos" (El Mundo, 21 noviembre 1996) a Fidel Castro y al Papa Juan Pablo II, con motivo de un encuentro entre ellos en Roma. Sin embargo, el texto no es en sí un retrato poético, ni tan siquiera un retrato no poético de estos dos personajes, sino valoración de un hecho político, en torno a la idea (periodismo de opinión) de que son ambos, cada uno a su modo, combatientes "en la guerra contra el capitalismo fin de siglo". Ahora bien, entremete Umbral en el texto retratos poéticos breves. Uno de estos está entre el rechazo, la admiración y la compasión que le merecen como políticos y como ancianos. Y ello a través de la lírica imagen del ángel:

Son dos ángeles caídos, Fidel y el Papa, con alas de periódico en su nostalgia del lodo, asqueado uno, víctima el otro, de las metrópolis donde el dólar canta como un ciego millonario en una esquina de Wall Street. El ángel de uniforme, viejo y barbado, parece más bíblico que el ángel cristiano, ángel ya de sepulcro, de panteón blanco y mármol terminal.

En otras ocasiones, se desliza el retrato poético breve de un político dentro de un texto no dedicado en absoluto al personaje. En el artículo "El español y los ángeles", Umbral (1989, pp. 189-93) usa otra vez la imagen del ángel para reflexionar sobre cuestiones sociológicas en torno a la idea de que: "Todos los españoles tenemos nuestro ángel de la guarda" (p. 189). Y así desliza varios retratos poéticos breves, como este alabando a Pablo Castellano, político socialista que se salió del PSOE para fundar el Partido de Acción Socialista (PASOC) e integrarse luego en Izquierda Unida: "hay, en la política, un ángel rebelde, Pablo Castellano, ángel caído de los cielos velazqueños de la Moncloa" (p. 190). En la entrada del 5 de noviembre de 1997 de su Diario político y sentimental, Umbral habla de diferentes eventos de sociedad: entregas de premios, cenas de gala y, concretamente, una charla que da en la Universidad Carlos III. Acompañado para la ocasión por Gregorio Peces-Barba, uno de los padres de la Constitución, diputado (1977-1986), Presidente del Congreso (1982-1986) y, por aquel entonces, rector de la susodicha universidad, Umbral aprovecha para entremeter un retrato poético breve: “Grande y seguro, es como un ángel de la Biblia que ha engordado algo, como un espíritu puro embarnecido por la cultura" (Umbral, 1999, p. 97). En otro lado, Umbral habla del papel político de los obispos, y critica particularmente al cardenal Marcelo González Martín, de quien puede destacarse este retrato antipoético breve: "Era como el obispo leproso de Gabriel Miró, comido de una lepra de oro y escolástica, ardido en su propia ira santa" (Umbral, 1993, p. 174). Umbral no solo se vale de un símil de resonancias muy figuradas y de fuerte colorido sinestésico, sino que lo hace refiriéndose a Gabriel Miró, autor admirado cuya obra también ha sido estudiada por su fuerte carga poética (véase Laín Corona, 2014b, pp. 123-174).

Como puede apreciarse, el grado de poeticidad depende de la intensidad y abundancia de ciertos 
rasgos, pero ello, en última instancia, depende de un modo subjetivo de apreciación del texto. Ya se ha mencionado el peso de la tradición romántica en la concepción de la poesía (no en balde, Octavio Paz hablaba en 1974 de Los hijos del limo: del Romanticismo a la Vanguardia), de modo que al lector le debe resultar más fácil apreciar la poeticidad de textos que tratan de ciertos temas, como la melancólica despedida de Fernando Morán, que apreciar la poeticidad de los retratos antipoéticos en que Umbral critica y se burla de políticos. De hecho, Umbral es mucho menos prolijo en estos casos en rasgos poéticos. Tal vez por esta razón son poco frecuentes los retratos antipoéticos autónomos, pero los hay. En su Guía de pecadores/as (1986), Umbral hace un diccionario de las personalidades más relevantes (no solo políticos) de España. Las entradas, en orden alfabético son autónomas (como en todo diccionario), y algunas, aun sin ser poemas en prosa como tales, tienen tantos rasgos poéticos, que pueden considerarse retratos poéticos autónomos. Así, por ejemplo, la entrada de "Alzaga, Óscar" (Umbral, 1986, pp. 18-19), sobre el cofundador de la Unión de Centro Democrático (UCD) y del Partido Demócrata Popular (PDP), que finalmente se integrarían en el Partido Popular. Criticando que su estrategia es maquillar de demócrata el antiguo nacionalcatolicismo, Umbral abunda en insultos llenos de satírica poeticidad, como por ejemplo: "Conserva el aspecto del niño que se levantaba siempre a leer, en la clase de lectura, porque era el que mejor ponía los diptongos. Todo él es un poco dispongo" (p. 18). La última frase recuerda al famoso verso de Jorge Guillén (1968, p. 85) en su poema "Cima de la delicia": "Todo en el aire es pájaro". Con esta imagen, Umbral quiere decir que Alzaga trata "de poner el diptongo demócrata en la letanía de sus fieles", de fuerte base nacionalcatolicista, y por ello concluye antipoéticamente: "Su partido es algo así como el beaterío de Santa María Egipciaca, pero con los egipcios vestidos de terlenka" (p. 19). Con referencia al tejido que se popularizó a partir de los 60 como signo de modernidad en el vestir, Umbral insiste en el carácter a dos bandas: ultraconservador vestido de apariencia moderna.

Menos frecuente aún, aunque más fácilmente identificable como tal, es el retrato anitpoético autónomo en forma de poema en verso. Por ejemplo, "Carta de Antonio Machado" (El Mundo, 31 mayo 1990), contra Alfonso Guerra (diputado socialista desde 1977 y Vicepresidente del Gobierno entre 1982 y 1991). Véase el comienzo, con referencia al caso de corrupción que envolvió a su hermano Juan Guerra:

\begin{abstract}
Alfonso de la guerra y de la idea,
español, sevillano y socialista,

llega hasta mí tu voz partenopea

y me dicen que tienes mucha vista.

Y me dicen que tienes mucha vista

por asco de la greña jacobea,

y que tu hermano Juan es un artista

de la zaragatera España macabea.
\end{abstract}

Si infrecuentes son los retratos antipoéticos autónomos, no lo son los retratos antipoéticos breves, esto es, las pinceladas poéticas de burla integradas en textos más amplios. En este sentido, hay retratos antipoéticos de tono lírico, diferentes del tono satírico del poema anterior. Umbral (1993, pp. 233-35) habla otra vez de "Alfonso Guerra" en La década roja, pero no en un retrato como tal, sino en un texto en que se analiza su comparecencia "para dar explicaciones sobre el caso de su hermano Juan Guerra" (p. 233). Intercaladas en este texto amplio, hay breves pinceladas, aunque de ataque, líricas: "[Alfonso] Guerra tenía en sus gafas todo el oro falso de las luces del Congreso y el foco de los protagonismos le daba en la cara como al mago del cabaret, no como al patricio aureolado" (p. 235).

Repitiendo, en otro lado, la imagen del ángel, critica Umbral (1984, pp. 246-48) "El ángel de lo fáctico", esto es, el hecho de que en España, por desgracia: "Vagos ángeles fácticos, custodian y presiden de continuo nuestra vida. Lo que les diferencia de nosotros no son las alas, sino la pistola" (p. 246). Excepto breves comentarios como este, se trata de un artículo de opinión de tono más o menos prosaico lamentándose de la tradición de la fuerza bruta en la sociedad española. Pero inserta Umbral breves retratos antipoéticos líricos, como este en torno a Antonio Tejero, el guardia civil que fue el protagonista más visible del golpe de estado de febrero de 1981: "Ese ángel de charol y violencia que descendió sobre las Cortes españolas, instalándose en la hemicosa toda una noche, esperando improbables mensajes de un cielo militar y revuelto, convirtiendo el adunamiento de los diputados y el Gobierno en un almacén de patatas y sacos que fumaban" (p. 247). El uso metonímico del charol para referirse al tricornio sugiere la poética influencia de Federico García Lorca, tan admirado por Umbral desde muy pronto (considérese su libro Lorca, poeta maldito (1968)), por su célebre "Romance de la Guardia Civil española" (García Lorca, 1999, pp. 122-27): "Con el alma de charol / vienen por la carretera" (vv. 7-8). Por su parte, en "La manicura del tigre" Umbral 
(2007, pp. 171-177) habla de "la labor de los generales de Franco que le ayudaron a ganar" la Guerra Civil (p. 171), y a raíz de ello incluye un retrato antipoético breve sobre el dictador, feroz pero lírico: "Franco muere en la cama, sepultado como un personaje egipcio de zarzuela" (p. 172).

Merece la pena detenerse, por su belleza, en una columna que escribe Umbral en forma de poema en prosa (alejandrinos y endecasílabos), reivindicando "La paz" (El Mundo, 4 marzo 2003) frente a la inminente II Guerra de Irak: "La paz es una nieve con pisadas de lobo, / la paz está en los árboles como pájaro intacto, / no se atreve a pisar las hectáreas del odio / y vive en las pancartas de las muchachas nuevas". Con no estar dedicado a un político en particular, no es un retrato como tal, pero sí se intercala esta antipoética pincelada contra George W. Bush (Presidente de EE.UU., 2001-2009) y José María Aznar (Presidente del Gobierno de España, 1996-2004): “El rey americano con su Stetson, / el muchacho español en andas de la Historia". Umbral se refiere a la marca de sombreros, asociada al prototipo del cowboy, y sugiere que Aznar buscaba hacer la guerra por interés de destacar en la historia política.

Frente a estos ejemplos, de tono lírico en su ataque, el retrato antipoético breve de Umbral suele ser satírico y agresivo, aunque no por ello falto de poeticidad. En su columna "El vídeo" (El Mundo, 20 febrero 1996), Umbral reflexiona sobre un spot de campaña electoral del PSOE, en el que se muestran los presuntos males que podrían acontecer a España de ganar el PP las elecciones. A Umbral le hubiera parecido más efectivo mostrar a José María Aznar "tal y como es". De aquí se derivan varios retratos antipoéticos breves, sobre, por ejemplo, la sonrisa de Aznar, "como el que tiene un divieso en el cuello o bajo el bigote", de donde saca Umbral esta comparación cargada de poeticidad satírica: "Aznar como un Chaplin con dolor de muelas". Meses después, Umbral se mofa de que "Aznar lee a Kipling" (El Mundo, 3 mayo 1996), señalando que "no da la talla" para ello, y entremete un breve retrato antipoético: "Es un Lancelot de seda catalana y alpaca de entretiempo que no va a conquistar nada, sino que los viejos reinos súbditos le han conquistado a él". De manera similar se burla de Miguel Ángel Rodríguez en su época de Secretario de Estado de Comunicación (1996-1998) con Aznar, por considerarle un político vacío, que no dice nada. Aunque titulado "Rodríguez" (El Mundo, 23 octubre 1996), no es este artículo un retrato antipoético autónomo, porque no está dedicado en exclusiva a este político ni se mantiene cons- tantemente el tono poético en todo el texto. Pero hay varios retratos antipoéticos breves en torno a la idea de la Nada, como este cultivado de metáforas: “El señor Rodríguez es subsecretario de la Nada, ministro del atardecer, portavoz del silencio, guapo por su casa, vallisoletano (dicen) de pro, joven sin venir a cuento, político/sorpresa que no hace política y señor de ojos grandes para fascinar columnistas femeninas". Así, concluye Umbral: “El señor Rodríguez es un arcángel San Gabriel que no tiene nada que anunciar a una Virgen que no ha venido".

De rasgos más claramente poéticos, pero con el mismo tono mordaz, son tres epigramas que incluye Umbral en su "Epigramario urgente" (El Mundo, 13 junio 1996). Y es que Umbral se vale de un género poético satírico por excelencia, en el que destacaron maestros latinos como Catulo y Marcial. Umbral sigue el modelo más reciente de Jaime Campmany en El jardín de las víboras (1996), y, a lo largo de su argumentación periodística, ofrece tres epigramas de confección propia que funcionan como retratos antipoéticos breves dentro del artículo (las barras, en este caso, son el propio Umbral):

Político hay que buscar / que nuestra España gobierne, / político que sea terne / y pronto lo hemos de hallar. / Aznar.

Aunque le aqueje la gripe, / aunque la izquierda esté sola, / aunque llueva Sarasola, / aunque a ustedes no les flipe. / Felipe.

Aunque la dama es muy bella, / aunque su risa la ensancha, / aunque hoy es mujer sin mancha, / todos pensamos en ella. / Botella

Como ya se ha explicado, el receptor actual percibe más fácilmente la poeticidad de ciertos temas, especialmente los laudatorios, incluso en prosa, a causa del peso de la tradición romántica, que ha impuesto la identificación de poesía y lírica. Pero que para el receptor actual sea más difícil percibir la poeticidad de la sátira no significa que no exista. En efecto, al usar un marcador poético tan explícito como el epigrama, con verso y rima, Umbral está haciéndole evidente al lector la poeticidad de su burla. Pero la tradición poética satírica es mucho más amplia, aun si es menos explícita:

Quevedo, Larra, Ramón Gómez de la Serna. De entre toda la literatura madrileña, copiosa, revuelta, caliente, habladora, esos tres nombres. Quevedo es el arrebato; Larra, la lucidez; Ramón, el lirismo. Con arrebato, lucidez y lirismo quisiéramos escribir, haber 
escrito de Madrid. Quevedescamente, larranianamente, ramonianamente. (Umbral, 1977, p. 9)

Con estas coordenadas, por tanto, es más fácil remarcar la poeticidad de cierto tipo de retratos antipoéticos de carácter satírico-burlesco. Así, para el poema contra Alfonso Guerra antes analizado, Umbral está sin duda bebiendo del Quevedo de, por ejemplo, su soneto "A una nariz". Pero también para otros casos menos evidentes y aun no en verso. Analizando la sociología de Marbella, introduce Umbral comentarios muy satíricos contra Jesús Gil y Gil, quien fuera corrupto alcalde de esa ciudad entre 1993 y 2002. Algunos de los comentarios, con fuerte poeticidad en su formulación, pueden particularizarse como retratos antipoéticos breves de tono satírico quevedesco: "Gil, vestido de explorador y de fiera al mismo tiempo, es una jungla completa, una manigua recalentada por la parte de sus partes" ("Olor a Gil", El Mundo, 6 junio 1999). Se refiere Umbral a que Gil se amolda según la conveniencia para sacar el mejor partido, y así es todo él una amalgama (jungla, manigua) de cosas, ideas e intereses, y se enfada fácilmente (por la expresión vulgar calentar los cojones y en relación con que jungla y manigua son espacios naturales tropicales que se calientan al sol).

Pero, para la poeticidad de sus retratos antipoéticos breves, Umbral hubo de inspirarse también en la greguería ramoniana, según "la conocida fórmula aritmética greguería = humorismo + metáfora" (Gómez Yebra, 1994, p. 30). Pese a lo difícil que es definir las greguerías de Ramón Gómez de la Serna, hay rasgos constantes: "predomina en ellas la distensión, el buen humor, la gracilidad, el ingenio, la agilidad mental y el lirismo" (Gómez Yebra, 1994, p. 33). O sea, se trata de una sentencia breve ingeniosa que busca causar un tipo de sorpresa (a menudo, humorística) en el lector, usando rasgos propios de la lírica. Estos rasgos se repiten en Umbral, y entroncan con la tradición áurea. Según Torrente Ballester (1961, pp. 303-304): “la greguería es el resultado de una intuición que adivina la singularidad absoluta de los objetos y la expresa en un aforismo por medio de una comparación, de una imagen o una metáfora sustantiva o adjetiva, destacando ante todo el matiz humorístico del objeto". La greguería, pues, es una especie de aforismo sin enseñanza moral, y el aforismo lo cultivó Baltasar Gracián en el mismo marco literario que Quevedo. No es baladí, por otra parte, que Ramón compusiera poemas en secreto y que su vena poética la plasmara sustancialmente en su prosa, dándole cualidades propias de la poesía, como, en ocasiones, la rima (Gómez Yebra, 1994, p.
36). Ramón, por tanto, como luego Umbral, fue un prosista con alma de poeta, y le dio a su prosa, particularmente a sus greguerías, rasgos de poeticidad. $Y$ una última curiosidad: la ingente producción periodística de Umbral es equiparable a la ingente producción de greguerías de Ramón: Gómez Yebra (1994, p. 22), para la preparación de su edición, coteja nada menos que treinta mil greguerías, frente a "los cinco millones que defendía algún crítico".

Un recurso muy usado por Ramón para sus greguerías es la comparación con como (Gómez Yebra, 1994, p. 43), a menudo con una fuerte carga humorística: "Las berenjenas son como maduros badajos de campana" o "El 'maitre' es como el novio del restaurante" (Gómez de la Serna, 1994, p. 121). Aplicando esta técnica a un político, Umbral entremete esta greguería en su artículo "De Aznar a los Austrias" (El Mundo, 29 noviembre 2000): "Un presidente que es como una estatua de la Isla de Pascua con corbata". En otro lado, refiriéndose a una visita a la España franquista del dictador de la República Dominicana (1942-1952) Rafael Leónidas Trujillo, se mofa Umbral (1992, p. 297) poética y greguerescamente: "Los dictadores son como niños intercambiándose juguetes. Muy al fondo, como tapiz sombrío de la escena, seguía la represión" (en alusión a un intercambio de condecoración con Franco). Aquí, la primera comparación se complementa después del punto con otra, pero ello también en sintonía con ciertas greguerías de Ramón más extensas. Véase, por ejemplo, esta, en la que hay también cierta crítica social: "El certificado de vacuna vuelve a hacer párvulo al hombre. Por eso el emigrante llega como un niño que va a comenzar la vida al lugar de destino" (Gómez de la Serna, 1994, p. 219).

No siempre se vale Ramón de la comparación con como. Con la estructura metafórica de $A$ es $B$, "construye Ramón un sinfín de greguerías" (Gómez Yebra, 1994 , p. 44), como esta, en la que aborda humorísticamente un tema de sociedad: "Comer en una embajada es comer protocolo con salsa tártara" (Gómez de la Serna, 1994, p. 178). Temas de sociedad son los que incluye Umbral constantemente en sus columnas, entremetiendo greguerías humorísticas similares. Hablando de Juan Pablo II, dice: "un anciano que es todo él una ruina del Renacimiento con epilepsia" ("Y Ana se cruzó de piernas", El Mundo, 13 mayo 2003). Se burla de Nicolás Sartorius por ser aristócrata y comunista (miembro del PCE y portavoz de Izquierda Unida en el Parlamento entre 1986 y 1993): “Nicolás Sartorius era la ortodoxia leninista con alfiler heráldico en la corbata, y actualmente tira a socialdemócra- 
ta y enseña más que nunca los gemelos con escudo" (Umbral, 1993, p. 342). En cierta ocasión, se cachondea Umbral de "El polen de la derecha" (EI Mundo, 25 mayo 1990), esto es, de que el PSOE culpara a la derecha del aumento de las alergias debidas al polen, y sentencia irónicamente a modo de greguería $A$ es $B$ : "la derecha es una acacia de convento que echa polen para que estornuden los rojos".

Asumiendo la greguería para su presente, Umbral se refiere a menudo al imaginario colectivo contemporáneo. En un artículo en el que habla de "El español y el gay", Umbral (1989, pp. 95-99) critica el sentimiento machista subyacente a la homofobia, culpa al machismo de la razón de ser de las guerras, y retrata, por ello, a Ronald Reagan (Presidente de EE.UU., 19811989) de este modo gregueresco: "Reagan es hoy el supermacho galáctico que traiciona a Nancy con el Universo. Quiere violarlo todo" (p. 98), en referencia a su programa armamentístico, conocido popularmente como Guerra de las Galaxias. Y, en su Diario político y sentimental, alaba, humorísticamente, a un político y ataca a otro con sendas greguerías: "Felipe es un viejo rockero con la guitarra hecha astillas y la baraja trucada. Borrell es una spice girl con toda la marcha"4. En otro lado, Umbral se mofa de que "Sadam Husein con boina negra es como el chapapote sobre las rocas de la mar" ("La peste política", El Mundo, 7 febrero 2003), en referencia al vertido de petróleo en Galicia tras el desastre del Prestige en 2002.

La poeticidad del retrato antipoético breve tiene que ver también con lo que Umbral califica como uso condensado de la imagen: "dar una idea mediante una imagen, es la huella digital del escritor, por la que se conoce al que lo es de raza: pluma capaz de sintetizar todo un mundo mental o sociológico en un rasgo de gran visualidad". Y añade, en relación no casual con la tradición literaria ya señalada aquí: "No de otra forma han escrito Quevedo, Valle-Inclán o Cela" (“La fusta y la espuela”, El Mundo, 13 junio 1990). Esta técnica puede ponerse en relación con Marcel Proust, cuya deuda, estudiada recientemente (Díez Fernández, 2012), el propio Umbral reconoce en muchas ocasiones. Gérard Genette (1989, p. 96) ha estudiado en Proust expresiones del tipo “M. de Talleyrand, ese Roger Bacon de la naturaleza social" como deudoras, en su estructura ( $x$, ese $y$ de $z$ ) de Balzac. En Umbral se encuentran muchos retratos antipoéticos breves de este tipo, condensando un abanico de ideas sobre un personaje. Por ejemplo, de Josep Borrel, citado antes, se burla Umbral (1991a, p. 244) por sus ocurrencias sobre los impuestos, y le describe como "este Robert
Redford de la fiscalidad", porque, por otro lado, le reconoce su buena presencia e imagen. En "Misión de amor" (El Mundo, 1 septiembre 1990), Umbral habla de "[François] Mitterrand, ese De Gaulle de izquierdas", por su belicismo al apoyar la primera Guerra de Irak cuando fue Presidente de Francia (1981-1995).

El análisis de los retratos poéticos de Umbral no estaría completo sin tener en cuenta el factor diacrónico. Como señalaba Castellani, en su última etapa en El Mundo Umbral producía textos de carácter más marcadamente político y menos poético, y ello se refleja también en sus retratos. Por un lado, Umbral dedica menos columnas a alabar a los políticos, y ya se ha dicho que sus retratos de alanza son los de poeticidad más marcada o, al menos, evidente para el lector actual. Por otro, cada vez más entrado el siglo XXI, los ataques de Umbral se hacen más burdos y directos. No desaparece del todo la poeticidad en sus ataques. De José Luis Rodríguez Zapatero (Presidente del Gobierno, 2004-2011) se burla en alguna ocasión con cierto tono poético-satírico, al comparar, por ejemplo, su reivindicado talante conciliador con la sonrisa de la Gioconda, y llamarle por ello el Giocondo, en referencia metaliteraria a su propia novela El Giocondo (1970): "Rescatando un viejo título mío, que más vale olvidar, y atendiendo al carácter permanente de su sonrisa, apodaríamos a Zapatero como el Giocondo o la Gioconda [...] Elegir la risa como arma de gobierno es tan peligroso como elegir la mueca del matón, del jugador tramposo o del político que va a lo suyo" ("El Giocondo", El Mundo, 28 abril 2004). Sin embargo, ni siquiera en este texto es posible individualizar una frase a modo de retrato antipoético breve, y lo que se respira, más que poeticidad, es literariedad, y muy leve. En todo caso, por estos años, prevalecen las reflexiones propias del periodismo de opinión y ataques viscerales, como aquí, repitiendo la idea de la sonrisa pero sin deje poético alguno: "El señor Zapatero nos está llevando, sin perder la sonrisa, a un caos nacional que tampoco tiene motivaciones claras" ("La Revolución", El Mundo, 3 julio 2006). Del mismo modo, en las pocas ocasiones en que alaba a un político en esta época, Umbral ofrece la lisonja indisimulada y para nada poética. Entonces, su político más admirado es Mariano Rajoy, actual Presidente del Gobierno: "No pretendemos en esta columna proclamar la superioridad de nadie, sino dejar la cuenta y subrayar que Rajoy es [...] un hombre excepcional para el poder o la oposición" ("Rajoy presidenciable", El Mundo, 13 febrero 2007). 
Tampoco tienen una poeticidad marcada las referencias a políticos en los años que van hasta finales de los 70, tal vez porque todavía no ha depurado Umbral un estilo poético para su labor periodística (aunque ya está produciendo textos de marcada poeticidad en otros campos, como Mis paraísos artificiales, 1976). Con la sátira en cierto modo poética antes analizada, puede espigarse como retrato antipoético autónomo un artículo de Umbral (1976, pp. 57-58) sobre Laureano López Rodó (Ministro de Asuntos Exteriores en 1973, y posteriormente diputado en Cortes por Alianza Popular). Umbral se mofa de su papel durante el desarrollismo: "hombre del desarrollo, tiene calva digna, peinada para un lado, tiene los ojos grandes, abultados por las gafas, tiene un labio grueso, ni de lascivia ni de baba, y tiene la camisa blanca, blanquísima, pulimentada con todos los detergentes ideológicos de la Obra". Se refiere Umbral al Opus Dei, y luego, con cierto tono lírico, pero sin dejar de ser burlesco, habla de su función de embajador en Viena, como si fuera un exilio: “López Rodó, viajero en bicicleta por los cielos pomporé de una Viena extinta, baila el vals de la soledad, el vals de las olas y las velas nostálgicas, a solas con sus recuerdos, esperando volver a recristianizar España y la peseta" (Umbral, 1976, p. 57).

En todo caso, por estos años, si se puede espigar algún retrato poético, no suelen ser autónomos, sino breves, integrados en textos más amplios. Comentando que lo normal es que haya rumores antes de los nombramientos de nuevos miembros de gobierno, dice Umbral (1975a, p. 25): "Precedido del rumor, que es el perfume de la noticia, ha llegado Fernando Suárez, como el aroma precede al clavel. Voz de clavel varonil [...] zapatos color de régimen, medallones de marfil y medallas políticas que le llevan hoy a la Vicepresidencia tercera del Gobierno y al Ministerio de Trabajo". Aquí, la poeticidad del retrato satírico se ve reforzada por la referencia al romance de Lorca (1999, pp. 107-09) sobre la "Muerte de Antoñito el Camborio", de quien se dice que tiene "voz de clavel varonil" (vv. 4 y 22), así como "Zapatos color corinto, / medallones de marfil" (vv. 29-30 $)^{5}$. En otro lado, al hablar de José Luis Cerón Ayuso (Ministro de Comercio con Franco, 1975), Umbral hace un comentario que prefigura los retratos tipo greguería: “El señor Cerón es una especie de Kissinger a la española, con el bigote de López Vázquez y las gafas llenas de números" (Umbral, 1975b, p. 20).

Así, puede decirse que la época de mayor poeticidad en sus retratos de políticos se da entre los 80 y primeros años del siglo XXI. Esta evolución cronológica no impide encontrar algunos retratos de alta poe- ticidad en los 70 y en la última etapa de Umbral. Ello depende, en parte, de lo que decía Castellani. Cuando Umbral se desentiende de la crónica política como tal y toma al político como pretexto de otra cosa, se da un mayor grado de poeticidad. Así ocurre con la elegía. De los 70 es su "Carta a Pablo Neruda" (Umbral, 1975a, pp. 339-40). Aunque dirigida al poeta chileno, se trata de una lamentación por el asesinato del socialista Salvador Allende. Pero precisamente por no centrarse en el que fuera Presidente de Chile (19701973) ni en su política, sino en el sentimiento que su muerte produce en el poeta destinatario de la carta y en Umbral, este logra uno de sus textos de mayor poeticidad de esta época, y puede tomarse como retrato poético autónomo de alabanza. Aunque todavía no en prosa metrificada, se lee un melancólico lirismo y un cuidadoso lenguaje, sazonado con referencias a la obra poética de Neruda:

[Allende] tenía esa fe y hoy, ya tan tarde, tú te quedas sin esperanza, sin futuro, frustrados tus versos, truncada toda tu obra, roto el alejandrino rubeniano y rota la oda elemental y callejera. Aquí termina el canto general, por ahora, aquí termina todo el amor, y tu país se oscurece, no en las manos del día, sino en las garras humeantes de la noche. (p. 340)

Dolorido, Umbral concluye con una referencia metafórica, escéptica, pesimista, pero hermosísima, a las políticas socialistas: "Inútil nacionalizar el sol cuando vienen tiempos de sombra" (p. 340).

Este tipo de retrato poético con función elegíaca lo repite Umbral en varias ocasiones. En el artículo "Enrique Múgica" (El Mundo, 9 febrero 1996), Ilora la muerte del hermano de este a manos de ETA. Umbral, que admira al que fuera, entre otros cargos, Ministro socialista de Justicia (1988-1991), considera que su buen hacer como político ha sido socavado por el atentado contra la vida de su hermano, y organiza su texto en prosa metrificada:

Han derribado a Enrique / derribando a su hermano, / una muerte vicaria, no le perdonan / que esparciese los presos, / esa medida desarticuladora. / Enrique, amigo vivo, amigo muerto, / llevarás el cadáver de tu hermano, / ese muerto interior, sonando a raza / y crimen dentro de tu gran pecho, / poderoso y entrañable judío vasco, / cabeza de romano o de fenicio, / Herzog, cruce de razas, / sobrino de Maurois, / socialista de luces y entrecejo, / nobilísimo vasco, / solitario y profundo, / lector, lector que tiene / algo, con un libro en la mano, / del Pensador de Rodin, hombre esculpido, / hecho para este caso. 
A diferencia de ejemplos anteriores, la metrificación de la prosa es poco clara por alguna irregularidad. Se ha propuesto una división en heptasílabos y dodecasílabos (dos hemistiquios: $7+5$ sílabas), pero hay un decasílabo y un eneasílabo (marcados en cursiva). En realidad, el decasílabo no es disonante si se tiene en cuenta que está formado por dos hemistiquios de cinco sílabas, como cinco sílabas tiene uno de los hemistiquios del dodecasílabo; o sea, el decasílabo es como una suma de dos hemistiquios cortos del dodecasílabo. En todo caso, la suma de dodecasílabos y heptasílabos con algún metro disonante es una variante de la metrificación que Pedro Salinas, poeta admirado de Umbral, usaba frecuentemente: endecasílabos y heptasílabos, con algún metro disonante. Sin ir más lejos, el poema de La voz a ti debida (1933) de Salinas (2001, pp. 363-64), que empieza "¿Las oyes cómo piden...", del que Umbral toma un verso como título de su libro Mortal y rosa, está escrito de este modo: predominan los endecasílabos y heptasílabos, con versos disonantes de 2 y 5 sílabas.

Para terminar, es interesante analizar los políticos que retrató Umbral, por más que, por límites de espacio, solo se puedan incluir unos pocos ejemplos de la enorme lista que manejó el autor. Cuando habla de mujeres, Umbral suele abstraerse de las cuestiones políticas y se centra, para bien o para mal, en su condición femenina: le interesa la mujer, no la política (aunque hay excepciones como las de Loloya de Palacio en su lucha contra la política agraria europea). Cuando es para bien, Umbral hace de la mujer una suerte de musa, que le inspira hermosas reflexiones lejos de la política. A Dolores Ibárruri, la Pasionaria, icónica líder del Partido Comunista de España, Umbral le dedica muchas y hermosas (líricas) palabras. Por ejemplo, la entrada de Guía de pecadores es un buen ejemplo de retrato poético autónomo, en forma de poema en verso (alejandrinos) y prosa metrificada (alejandrinos, con un heptasílabo suelto, y endecasílabos) [para mayor claridad, pongo en cursiva la parte en verso, y la parte en prosa metrificada va en redonda y con barras para señalar la metrificación]:

Dolores, Dama de Elche de los proletariados, / mujer, minera santa icono de los pueblos.

Dolores, blanco pelo como un ave de idea.

Dolores, digna frente, como el cofre de todo.

Dolores, hondos ojos, ilustrados de Historia.

Y la risa tan niña, la femenina voz / que sólo en los congresos se hacía soberbia y fuerte. / Y las manos de santa.
Y el pequeño pañuelo, con lunares, / en torno de su cuello de señora.

Señora de los pobres, pobre desde la muerte.

Dolores, honda hembra, la muchacha minera.

Rubén se llamó el hijo, murió en Stalingrado. (Umbral, 1986, p. 102)

Umbral reconoce el papel de la Pasionaria como líder de la izquierda proletaria, pero muy escuetamente, y en el fragmento citado (como en el resto del texto) destaca la belleza de sus atributos físicos (pelo, frente, ojos, risa, voz, manos), su atuendo y su maternidad truncada, de modo que se la define tajantemente como "honda hembra". De manera parecida, en Crónica de esa guapa gente, Umbral (1991b, p. 200) ofrece un retrato poético breve en torno a la edad de Ibárruri y su portentosa imagen: "Era una anciana alta y bella, era de esa aristocracia natural que da el pueblo cuando le sale una veta de ilustración y señorío. Era una vasca inmensa y vehemente". Y en formato de greguería: "era adorable como una niña de mil años, Alicia en el país de las pasionarias".

Muy parecido es el caso de Carmen Díez de Rivera, quien desarrolló una destacada carrera política, junto a Adolfo Suárez primero, y, luego con el PSOE, como eurodiputada (1987-1999). Pese a admirar y hablar de su carrera política, Umbral presta más atención a la mujer, y logra sus mayores logros poéticos cuando se refiere al cáncer que le arrebató la vida. Con motivo de su entierro, Umbral escribe "Crisantemos amarillos" (El Mundo, 4 diciembre 1999), una descripción del suceso entre la crónica periodística y la estampa lírica, donde resalta algún retrato poético breve: “Carmen ha sido una de las cabezas políticas más lúcidas de este siglo. Una mujer que era pura idea, amor mineral del mundo". En su Diario político y sentimental, que se lo dedica precisamente a ella, Umbral incluye varios retratos poéticos breves, y hace de la entrada de 16 de junio de 1998 todo un retrato poético autónomo, aun no estando en prosa metrificada:

Sin noticias de Carmen Díez de Rivera, que huyó a una casita de Menorca, solitaria. Otra figura frente a la muerte. Otra postura para morir.

La imagino nadando con un solo brazo en el mar agreste. Amazona del mar, mujer de un solo pecho, imagen nueva frente a las sirenas, mitología que ella inicia. El mar volverá rubio su pelo blanco y será la ondina/amazona que no va a pasar a las litografías de lo imposible, salvo esta viñeta de palabras que le hago yo ahora. (Umbral, 1999, p. 357) 
A veces, la abstracción respecto de las cuestiones políticas es tal, que la mujer no es más que excusa para hablar de otra cosa. El poema "Ana Botella, en malva" (Umbral, 2009, p. 277) podría tomarse como retrato poético autónomo de la esposa de José María Aznar y alcaldesa de Madrid entre diciembre de 2011 y junio de 2015. Pero ella le interesa como mujer, por su vestimenta, no como política, como muestra la cita de periódico que le sirve a Umbral de inspiración: “Ana Botella, esposa del presidente Aznar, ha aparecido en una fiesta con un conjunto malva". Así, el poema en realidad es una reflexión lírica sobre el color malva:
El malva es la memoria de un crepúsculo,
lo malva es la visita de un poeta,
es malva la memoria de las cosas,
es color malva aquello que se olvida.
No es el rojo, ni el rosa, ni el carmín,
no es un color, lo malva, es un recuerdo,
es la sombra cansada del violeta.

Al final muestra Umbral que lo que le fascina del malva es que proyecta, no ya a Ana Botella, sino a la mujer ideal, hermosa, que, a todas luces, por serlo, le gusta, pero no puede poseer ("rastro de una bella", "ausencia"), en vaga sintonía, si se quiere, con ciertas tradiciones de poesía de amor platónico y con cierto tono erótico ("fiebre", "rubor", "rojo"):
Una mujer de malva no es un luto
sino una realidad que va despacio.
Lo malva es la idea que tenemos
cuando sube la fiebre de las cosas.
Es una lenta fiebre, rubor dulce,
es el ángel cismático del rojo.
El malva está de moda, según dicen,
lo malva es un perfume que se ve,
el rastro de una bella,
o ya su ausencia.

En estos ejemplo, tan líricos, es difícil ver una actitud machista, pero podría tomarse como tal el hecho de que Umbral destaca a la mujer, ignorando o relegando a segunda posición su quehacer político. Donde sí es tremendamente machista es en sus retratos antipoéticos de mujeres, al valerse de recursos poético-satíricos para atacar a la política a partir de sus atributos femeninos. A Isabel Tocino, que llegó a ser Ministra de Medio Ambiente (1996-2000) con Aznar, Umbral la acusa muy insistentemente de estar a la sombra de Manuel Fraga, y esto lo relaciona casi siempre con su condición de mujer. Siguiendo en parte el modelo de imagen $x$, ese $y$ de $z$, de Proust/Balzac, Umbral ofrece este retrato antipoético breve: "Doña Isabel, ese Fraga con evax" ("Isabel Tocino", El Mundo, 10 enero 1990), en referencia a la menstruación y la marca de compresas. En otro lado, a modo de greguería, ataca su mala gestión como ministra refiriéndose a su coquetería en el vestir: "Isabel Tocino, amazona de Fraga, que se ha hecho del Medio Ambiente un pareo" (Umbral, 1999, p. 316). En el artículo "Tocino/Aznar" (El Mundo, 9 marzo 1990), Umbral abstrae a la mujer de su papel de política cuando dice que "es siempre muy alegórica -la Patria, la República, la Agricultura, la Caridad, la Repoblación Forestal-". Así, acusa a Tocino de ser "la alegoría, la metáfora, la fondona cariátide (en griego, bordadora) de las esencias fraguistas, de las fragancias de Fraga". Nótese la poética aliteración, después de lo cual se ofrece este retrato antipoético breve: "la evanescente y sólida Tocino, tan mítica entre la derecha como la dama/emblema del rolls". Con estilemas parecidos, hace Umbral una "Antología de tontas" (EI Mundo, 15 septiembre 1990) en la izquierda y la derecha, e incluye a Tocino: "la fraguista Tocino es tonta de Serrano, tonta/lottusse, tonta/Opel Vectra, tonta último modelo". Aquí subyace el tópico de que la mujer es consumista de moda, particularmente la mujer de recursos económicos que compra ropa en la calle Serrado de Madrid, con sus tiendas de marca de lujo, como Lottusse, y que quiere coche último modelo.

La mención a Manuel Fraga no es casual en Umbral. Histórico político del franquismo, clave, entre otros roles, como Ministro de Información y Turismo (1962-1969), luego en democracia fundó y presidió Alianza Popular (1976-1989), germen del actual Partido Popular, por el cual fue Presidente de la Xunta de Galicia (1990-2005). Fraga, por tanto, tuvo un papel destacado en la escena política española durante décadas, y así se convirtió en uno de los políticos más comentados por Umbral. Hay fundamentalmente retratos antipoéticos, porque Umbral siempre fue muy crítico con Fraga. En los 70, cuando Umbral todavía no ha desarrollado con fineza la poeticidad de sus artículos en Prensa, puede espigarse algún retrato antipoético breve. Con una referencia a la película Johnny cogió su fusil (1971), Umbral (1975d, pp. 7-9) escribe "Fraga cogió su fusil”, y se pregunta "¿Es Fraga un condotiero veneciano?" (p. 7) y “¿Es Fraga un Kennedy a la española?", a lo que responde: "Si para condotiero le sobra energía y le falta melena, para Kennedy le sobra Embajada y le falta Jacqueline" (p. 8). Por esas mismas fechas, tiene algo de retrato antipoético quevedesco el texto dedicado en Hermano Lobo 
a los pies de "Fraga" (Umbral, 1975c, p. 138): "En la rugosidad y callosidad de otro tiempo se adivina al niño montaraz de aldea galaica, que todavía tiene en la planta la mordedura de una víbora asilvestrada". De la entrada de Fraga en Guía de pecadores (Umbral, 1986, pp. 75-76), aunque no es en sí un retrato poético, se puede espigar algún retrato antipoético breve tipo greguería: "es el hombre/armario por sus hechuras personales y porque tiene la cabeza llena de armarios, como cierta virgen de Dalí" (p. 75). Sin embargo, la poeticidad es más marcada en otros textos, como en este retrato anitpoético breve en que Umbral ataca a Fraga con imágenes de tono lírico, por convertirse, ya en democracia, en una suerte de dictador regional: "presidente de la Baviera galaica, emperador de los afiladores y sus pacíficas cuchillas, que antañazo lo fuera de cuchillas y cuchillos más carnívoros" ("Grimau", El Mundo, 30 enero 1990). Aquí, la poeticidad se ve reforzada por la alusión al primer poema de Miguel Hernández (1996, pp. 79-80) en El rayo que no cesa (1936): "Un carnívoro cuchillo / de ala dulce y homicida" (vv. 1-2), que a Umbral le sirve igualmente de título para su libro Un carnívoro cuchillo (1988). También se refiere Umbral a menudo a la capacidad de Fraga para sobrevivir políticamente durante años, y así lo resume con la fórmula de $x$, ese y de z: "Fraga, este John Wayne eterno de nuestra política" ("El fragafederalismo", El Mundo, 3 abril 1996). Esa misma idea la repite más por extenso y con colofón a modo de greguería: "es el máximo ejemplo de político que ha atravesado mares y montañas, autonomías, nacionalismos, comunismos, socialismos y democracias no orgánicas. Fraga tiene unas botas de siete leguas y un marcapasos" ("Las botas de Fraga", El Mundo, 25 octubre 2004). Conmovido seguramente por su decadencia política y su senectud, Umbral se vuelve más condescendiente con los años, y surge entonces algún retrato poético breve de verdadera fuerza lírica, excepcional en su última etapa: "Con paso de procesión, con el mar pardo en su mirada, con una inteligencia que sueña, pero no duerme, Manuel Fraga Iribarne se pasea por los bosques animados de sus recuerdos y de su presente" ("Bamboleos de Fraga", El Mundo, 19 octubre 2006).

Junto a Fraga, el otro político al que Umbral se refiere incansablemente es Felipe González, Presidente del Gobierno por el PSOE entre 1982 y 1996. La obsesión por este socialista se debe a la desilusión que le produjo: Umbral esperaba una revolución que finalmente no fue, ya que en realidad supuso, según él, una forma de capitalismo socialdemócrata y corrupto. Son frecuentísimos los retratos antipoéticos, carga- dos de poeticidad en varios formatos. Para resumir su interpretación de los hechos, Umbral se vale de la imagen de "Los cisnes" (El Mundo, 22 marzo 1996), que le da para varios retratos breves, como este: "Es lo que tiene la política, y la vida misma: que a un cisne adolescente lo va convirtiendo en una oca gorda, vieja, ojerosa y cloqueante, infartada del paté y el foagrás de la corrupción". En otro lado, habla Umbral de la supuesta poca dignidad con que el político se está retirando de escena tras perder las elecciones:

Felipe González vino de cisne de Suresnes, allá por los setenta. Un cisne con jersey cuello de cisne. Hoy no es que se haya convertido en un pato patoso, sino más bien en una oca clueca que va anadeando por ahí, por los arrabales del Estado y las charcas de la primavera.

Se vale Umbral a menudo de la imagen del bonsái, dada la afición que tuvo González de coleccionar ejemplares de esta planta, y así le describe como "El señor de los bonsáis" (El Mundo, 15 febrero 1996) y desarrolla retratos antipoéticos breves como este: "un bonsái humano, monstruoso, como todo lo japonés, que crece hacia adentro, vive de sus propias raíces y ha llegado a esa otra forma de vida vegetal que es el Poder por el Poder" (Umbral, 1993, p. 108). En Crónica de esa guapa gente, en formato greguería, repite Umbral (1991b, p. 41): "Los bonsáis son sus rosas de otoño benaventinas". Y, más adelante, le critica su oratoria, en comparación con Fraga, también en formato greguería: “Lo que pasa con Felipe González es que habla él solo y todo el rato. Es el hombre/conferencia, como Fraga en la derecha" (p. 187).

Frente a estos retratos antipoéticos breves, de tono satírico-burlesco, destaca otro, también antipoético, pero autónomo y de tono muy lírico. Se trata de un artículo de El Mundo construido en su totalidad como poema en prosa metrificada (alejandrinos), en el que, a pesar de criticarle, Umbral muestra melancólica y líricamente su decepción ante el proyecto político de González:

Fuiste el gran esperado, el varón de los días, / fuiste un adolescente y unas botas civiles / que pisaron a tiempo lápidas del Caudillo. / Cogiste nuestro tiempo, nuestros años mejores / y te hiciste con ellos un luminoso ramo. / Hoy el cielo está seco sobre tu vieja historia / y te vas muy cumplido, ceniciento y ferralla. / Generación entera que contigo marchaba, / los agostos civiles que tu reinado trajo, / pero un dinero lento, un tiempo de banqueros / iba acarreando sombra sobre nuestras cabezas. ("Felipe", El Mundo, 6 mayo 1996) 
Como puede verse, y a modo de conclusión, el análisis de sus retratos de políticos muestra que el fenómeno poético en Umbral es eso: un fenómeno poético. Umbral no fue un poeta stricto sensu, en tanto que no se dedicó al género poesía como tal, o solo lo hizo esporádicamente y de manera diletante, o bien integrando lo poético en su producción literaria y periodística. Con esto no se quiere minusvalorar la obra de Umbral, ni tan siquiera el componente poético de sus textos. De hecho, tanto más genial y moderno resulta esta manera de hacer literatura, fusionando géneros. Sin embargo, se logra así un análisis más riguroso y se supera lo que se ha llamado mitología umbraliana, esto es, la alabanza ciega a través de sus virtudes poéticas, lo que, por cierto, puede resultar más perjudicial de lo que los admiradores de Umbral querrían: en la época del e-book, buscarle lectores a través del énfasis en sus rasgos poéticos tal vez no sea la estrategia más eficaz. Sea como fuere, el funcionamiento del fenómeno poético en Umbral queda muy claro en sus retratos de políticos. Umbral con frecuencia hizo de este tipo de textos retratos poéticos, esto es, con señales que tanto él (escritor) como los lectores han de percibir como propios de la poesía. Pero poemas de políticos, como tales poemas, hizo pocos. Incluso, en ocasiones, ciertos poemas (como tales) de políticos, al insertarlos en el espacio de la columna, pierden, según la teoría de la recepción, parte de su poeticidad, ya que la función poética se percibe subordinada a la periodística. Así, lo que en este artículo se ha hecho es un análisis del grado de poeticidad de sus retratos. Umbral hizo retratos poéticos en un sentido amplio: retratos positivos o negativos de políticos con marcas de poeticidad. En sentido restringido, retratos poéticos son aquellos que alaban al político, y retratos antipoéticos se considera aquellos en los que Umbral le hace burla o crítica. La poeticidad de los retratos poéticos (positivos y negativos) depende de la cantidad y calidad de las señales usadas para alabar o criticar. Así, se ha clasificado que un retrato poético autónomo es aquel texto por entero dedicado a retratar a un político con señales de poeticidad constantes. A veces, estos retratos poéticos autónomos son poemas en sí, en verso o prosa metrificada. El retrato poético no autónomo o breve es aquella pincelada de rasgos poéticos con que se alaba o critica a un político dentro de un texto más amplio que no es poético y/o no está dedicado en exclusiva al mismo. Por ejemplo, los retratos poéticos breves a modo de greguería. La mayor o menor poeticidad de estos retratos depende en gran medida de su carácter autónomo o breve. Como también depende de la época y del tema. Los retratos más poéticos de Umbral se concentran entre los 80 y el año 2000. Además, por influencia de la concepción postromántica de la poesía como lírica, se perciben como más poéticos los retratos de alabanza, y más aún aquellos en los que Umbral toma al político como excusa para otra cosa, como la elegía. Este artículo, pues, ofrece un análisis de los retratos poéticos que hizo Umbral de políticos, pero es ilustrativo de cómo funciona el fenómeno poético en su obra. Por otro lado, con este estudio se abre la puerta a un tema muy interesante: el pensamiento político de Umbral. Pero esto ya es materia de otro trabajo.

\section{NOTAS}

[1] De aquí en adelante, las columnas de Umbral en El Mundo se citan por el archivo online de su fundación: http:// fundacionfranciscoumbral.es/articulosel-mundo.php.

[2] Mi primera intuición fue relacionar este poema de Umbral con la poesía áurea. Nótese la similitud entre "oro de ley el denso pelo, / oro de ley el alma clara" y "media luna las armas de su frente, / y el sol todo los rayos de su pelo" de Luis de Góngora en las Soledades (I, vv. 3-4). En ambos casos, hay la misma estructura metafórica duplicada de forma paralela: (i) término imaginario (oro de ley, media luna) seguido de término real (el denso pelo, las armas de su frente), y (ii) otra vez término imaginario (oro de ley, el sol todo) seguido de término real (el alma clara, los rayos de su pelo), con la particularidad de que los términos reales de Góngora son a su vez metáforas en segundo grado. No obstante esta similitud, he de agradecerle al Dr. Gaspar Garrote Bernal su apreciación. Fino conocedor de la poesía del Siglo de Oro, me hizo ver que el lenguaje y la imaginería de Umbral en este caso no eran especialmente áureos, y me sugirió la mucho más cercana relación con el Modernismo, de donde llegué a Rubén Darío.
[3] Luego recogida en Diario político y sentimental.

[4] Felipe González fue Presidente del Gobierno de España (1982-1996). Tras su derrota, Josep Borrel fue el candidato del PSOE en 2000, y ya había ejercido de diputado (1993-2004) y miembro del gobierno de González (1991-1996).

[5] Debo darle las gracias al profesor Ignacio Díez por haberme resaltado esta valiosa referencia. 


\section{BIBLIOGRAFÍA}

Ansón, L. M. (24 julio 2009). Umbral, poeta en vilo. El Cultural [fecha de consulta: 24 noviembre 2014]. Disponible en http://www.elcultural.es/articulo_imp. aspx?id=25677

Brioschi, F. y Di Girolamo, C. (2000). Introducción al estudio de la literatura. Barcelona: Ariel.

Castellani, J.-P. (2009). Francisco Umbral y los géneros literarios. En: Sanz Villanueva, S. (ed.). Francisco Umbral y su tiempo. Valladolid: Ayuntamiento de Valladolid-Fundación Francisco Umbral, pp. 29-59.

Darío, R. (2000). Antología (ed. C. Ruiz Barrionuevo). Madrid: Espasa Calpe.

Díez Fernández, J. I. (2012). ¿Devoción de lector? El Umbral de Proust. En: Díez Fernández, J. I. (ed.). Los placeres literarios: Francisco Umbral como lector. Madrid: Fundación Francisco Umbral, pp. 79-95.

García Lorca, F. (1999). Romancero gitano. Sonetos del Amor Oscuro. Buenos Aires: Losada.

García-Posada, M. (2009). Introducción. El fenómeno poético en Francisco Umbral. En: Umbral, F. Obra poética (1981-2001) (ed. M. García-Posada). Barcelona: Seix Barral, pp. 7-26.

Genette, G. (1989). Palimpsestos: La literatura en segundo grado. Madrid: Taurus.

Gómez de la Serna, R. (1994). Greguerías (ed. A. Gómez Yebra). Madrid: Castalia.

Gómez Yebra, A. (1994). Introducción biográfica y crítica. En: Gómez de la Serna, R. Greguerías (ed. A. Gómez Yebra). Madrid: Castalia, pp. 7-63.

Góngora, L. de. (1994). Soledades (ed. R. Jammes). Madrid: Castalia.
Gracia Armendáriz, J. (2003). La obra periodística de Francisco Umbral: breve historia de una pasión diaria. En: Celma, M. P. (ed.). Francisco Umbral. Valladolid: Universidad de Valladolid-Junta de Castilla y León, pp. 85-99.

Guillén, J. (1968). Aire nuestro: Cántico, Clamor, Homenaje. Milán: All'Insegna del Pesce d'Oro.

Hernández, M. (1996). El hombre y su poesía (ed. J. Cano Ballesta). Madrid: Cátedra.

Laín Corona, G. (2014a). Más allá de la biografía real: Umbral como materia novelable. En: Buron-Brun, B. de (ed.). Francisco Umbral. Memoria(s): entre verdades y mentiras. Sevilla: Renacimiento, pp. 353-81.

Laín Corona, G. (2014b). Proyecciones de Gabriel Miró en la narrativa española de postguerra. Londres: Tamesis.

Ramoncín (Ramón J. Márquez). (2009). El quinta columnista. En: Sanz Villanueva, S. (ed.). Francisco Umbral y su tiempo, pp. 219-24.

Salinas, P. (1979). El signo de la literatura española del siglo XX. En: Literatura española. Siglo XX. Madrid. Alianza Editorial, pp. 34-45.

Salinas, P. (2001). Poesías completas (ed. S Salinas de Marichal). Barcelona: Lumen.

Torrente Ballester, G. (1961). Panorama de la literatura española contemporánea, I. Madrid: Guadarrama.

Umbral, F. (1975a). Suspiros de España. Madrid: Ediciones Felmar.

Umbral, F. (1975b). La guapa gente de derechas. Barcelona: Caralt.

Umbral, F. (1975c). Cabecitas locas, boquitas pintadas y corazones solitarios. Madrid: Ediciones 99
Umbral, F. (1975d). España cañí. Barcelona: Plaza \& Janés.

Umbral, F. (1976). Los políticos. Madrid: Sedmay.

Umbral, F. (1977). Amar en Madrid. Barcelona: Destino.

Umbral, F. (1980). La noche que llegué al café Gijón. Barcelona: Destino.

Umbral, F. (1984). España como invento. Madrid: Ediciones Libertarias.

Umbral, F. (1986). Guía de pecadores/as. Todos los que están. Barcelona: Anagrama.

Umbral, F. (1989). Guía irracional de España. Madrid: Arnao Ediciones.

Umbral, F. (1989-2007). Columnas de El Mundo [fecha de consulta: 24 noviembre 2014]. Disponible en: http://fundacionfranciscoumbral.es/articulos-elmundo.php

Umbral, F. (1991a). El socialfelipismo. Barcelona: Ediciones B.

Umbral, F. (1991b). Crónica de esa guapa gente. Memorias de la jet. Barcelona: Planeta.

Umbral, F. (1992). Del 98 a Don Juan Carlos. Barcelona: Planeta.

Umbral, F. (1993). La década roja. Barcelona: Planeta.

Umbral, F. (1999). Diario político y sentimental. Barcelona: Planeta.

Umbral, F. (2007). Amado siglo XX. Barcelona: Planeta.

Umbral, F. (2009). Obra poética (19812001) (ed. M. García-Posada). Barcelona: Seix Barral. 